\title{
NEW AND EXISTING BRIDGE CONSTRUCTIONS - INCREASE OF FATIGUE STRENGTH OF WELDED JOINTS BY HIGH FREQUENCY MECHANICAL IMPACT TREATMENT
}

Thomas Ummenhofer*, Head of Department, Chair for Steel Structures, Univ.-Prof. Dr.Ing., email: thomas.ummenhofer@kit.edu

Philipp Weidner*, Research Assistant, Dipl.-Ing., email: philipp.weidner@kit.edu Tim Zinke*, Research Assistant, Dipl.-Ing. Dipl.-Wirtsch.-Ing., email: tim.zinke@kit.edu *KIT Steel and Lightweight Structures, Research Center for Steel, Timber and Masonry, Tel. +49 721608 42215, Otto-Ammann-Platz 1,5 \& 7, 76131 Karlsruhe, Germany

\section{Abstract}

Numerous studies at KIT prove that high frequency mechanical impact (HFMI) treatment is an efficient method for increasing the fatigue strength of welded steel structures. Within different research projects it was found that HFMI-methods can be used successfully for new and existing structures in order to extend the fatigue life. This paper gives an overview of the current status of existing steel bridges in Germany regarding aspects like bridge age distributions and traffic loads. Based on that overview welded joints susceptible to fatigue failure are identified. Using component-like small scale specimens, HFMI-methods were investigated within the objective of implementing an effective application for new and existing structures. Applying the fatigue test data observed, existing design proposals are evaluated and design recommendations for HFMI-treated joints are given. As a result of the research work, a transfer into practice has been realized and different applications are illustrated using the example of bridge constructions made of steel.

Keywords: fatigue, welded structures, life-cycle, rehabilitation, high frequency mechanical impact (HFMI), fatigue strength improvement

\section{INTRODUCTION}

In recent years, optimization of new structures and also rehabilitation of existing structures have become an important issue worldwide. Bridge constructions, particularly welded steel structures, raise problems regarding fatigue behavior and durability. Implementing of new potentials for weight reduction as well as facing problems resulting from increased traffic loads, methods for enhancing the fatigue strength of welded structures gain in 
significance. As a result of different research projects and numerous studies at KIT (Karlsruhe Institute of Technology; Research Center for Steel, Timber and Masonry), it was proven that the fatigue life of new and existing structures can be considerably increased by the application of high frequency mechanical impact (HFMI) treatment [10-12, 17]. Due to the application of HFMI-methods such as High Frequency Impact Treatment (HiFIT), the weld toe is plastically deformed and compressive residual stresses are inserted in the weld toe region $[13,15]$. This leads to a retarded crack initiation and propagation [16], resulting in a higher fatigue strength and an extension of fatigue or service life. The HiFIT-device and -treatment of a welded joint is shown in Figure 1.
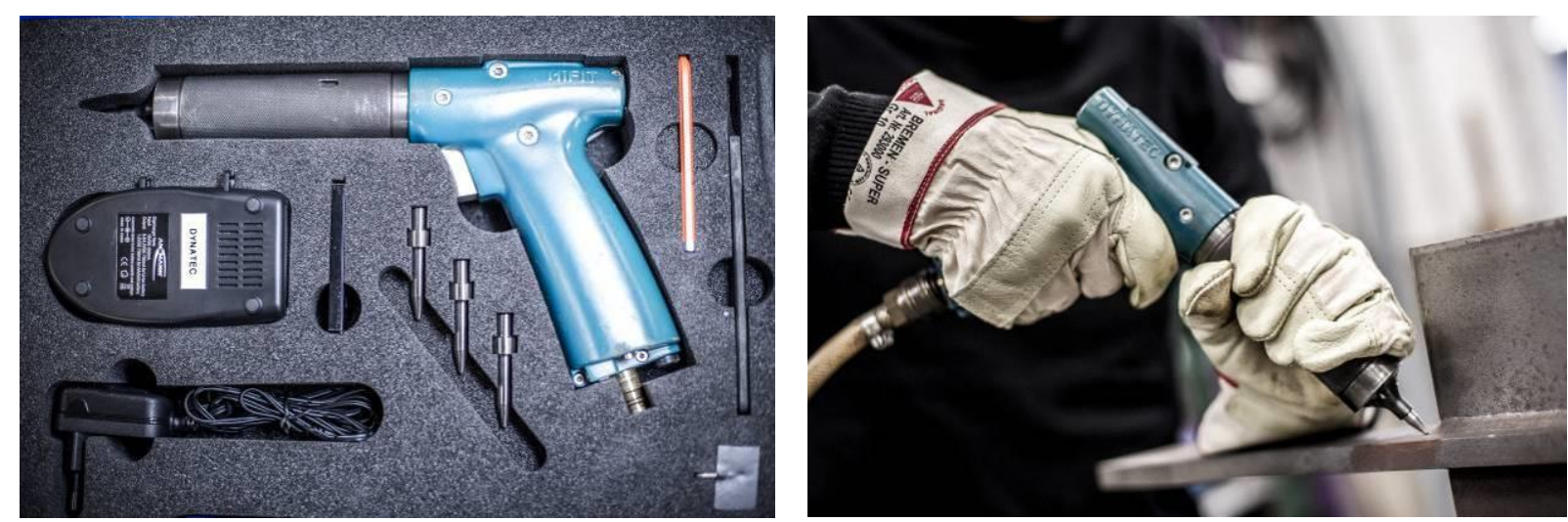

Figure 1. HFMI: HiFIT-device (left) and HiFIT-treatment (right)

Since Standards and recommendations [2, 5] assume that the fatigue strength of welded joints is independent of material yield strength, an efficient application of high strength steels in fatigue loaded structures is currently not possible. However, the status quo can be changed due to the fact that the efficiency of HFMI-treatment increases with higher material yield strength [11, 14]. Pursuing the strategy of weight reduction, an efficient application of high strength steels in fatigue loaded structures can now be realized using HFMI. Different proposals are available for the design of HFMI-treated welds. Because of the fact that the data used to establish the proposals has been derived from newly produced specimens, the applicability for existing structures with inherent fatigue damage remains to be verified. Based on extensive fatigue test data carried out at KIT, the application of HFMI-treatment on existing structures is discussed in this paper. 
ROMANIAN JOURNAL

OF TRANSPORT INFRASTRUCTURE

\section{EXISTING STEEL BRIDGES IN GERMANY}

\subsection{Initial situation}

In Germany, within the next ten years many old bridges reach the calculated end of their service life or have to be adapted to increasing loads. Basically, road and railway bridges have to be distinguished. In the German railway network, about one quarter of the bridges are made of steel, the other three quarters are made of concrete, masonry or sectional girders in concrete in equal shares. Within the road network the percentage of steel bridges is much smaller and stands actually at $5 \%$.
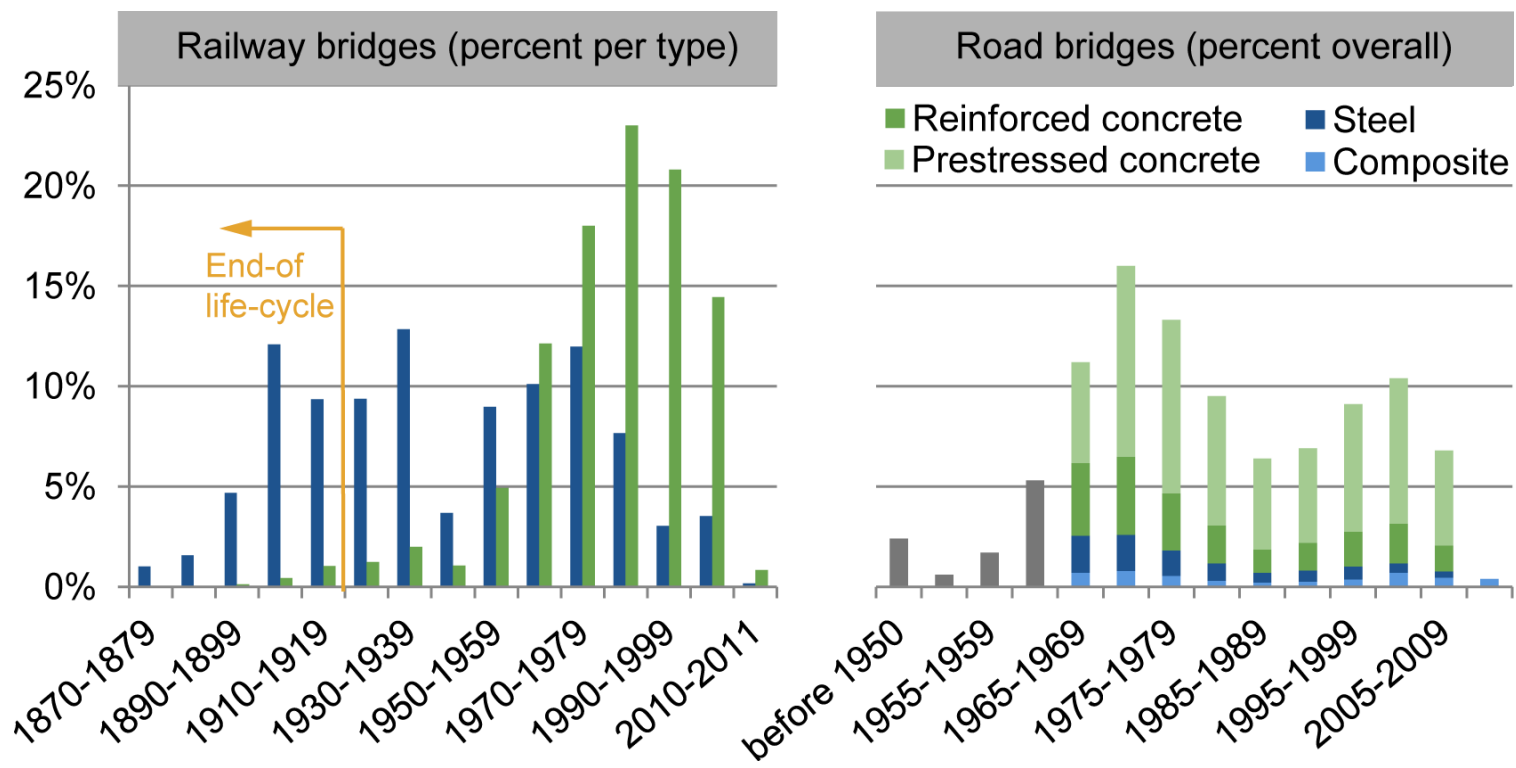

Figure 2. Age distribution of different bridge types for the railway network (left, percent per bridge type, only steel and reinforced bridges displayed) and the road network (right, percent overall per bridge deck area) $[1,8]$

The age distribution of railway bridges is shown in Figure 2 on the left side. Here, the ageing portfolio of bridges is apparent. About $25 \%$ of the steel bridges reach the end of their calculated service life within the next six years. As a solution, a replacement of the structures, rehabilitation or improvement must take place. Suitable methods have to be applied; high frequency mechanical impact treatment is one promising method to contribute to the implementation of rehabilitation and improvement. 


\title{
ROMANIAN JOURNAL \\ OF TRANSPORT INFRASTRUCTURE
}

\author{
Thomas Ummenhofer, Philipp Weidner, Tim Zinke \\ New and existing bridge constructions- increase of fatigue strength of welded joints by high frequency \\ mechanical impact treatment
}

The road bridge portfolio is much younger compared to the railway network and different kinds of structures are predominant, see Figure 2 on the right side. Most structures were built after 1960 and the share of steel and composite bridge is about $10 \%$ in 2010 . Since the portfolio is comparatively young, especially problems arising from the condition of the structures have to be solved.

\subsection{Condition index and safety aspects for road bridges}

For road bridges predefined inspection cycles are obligatory: one main inspection every six years, one mid-interval inspection every three years. Based on these inspections and the subsequent damage evaluations, the condition index is derived. The change of the condition index for all federal German road bridges between 2000 and 2010 is displayed in Figure 3.

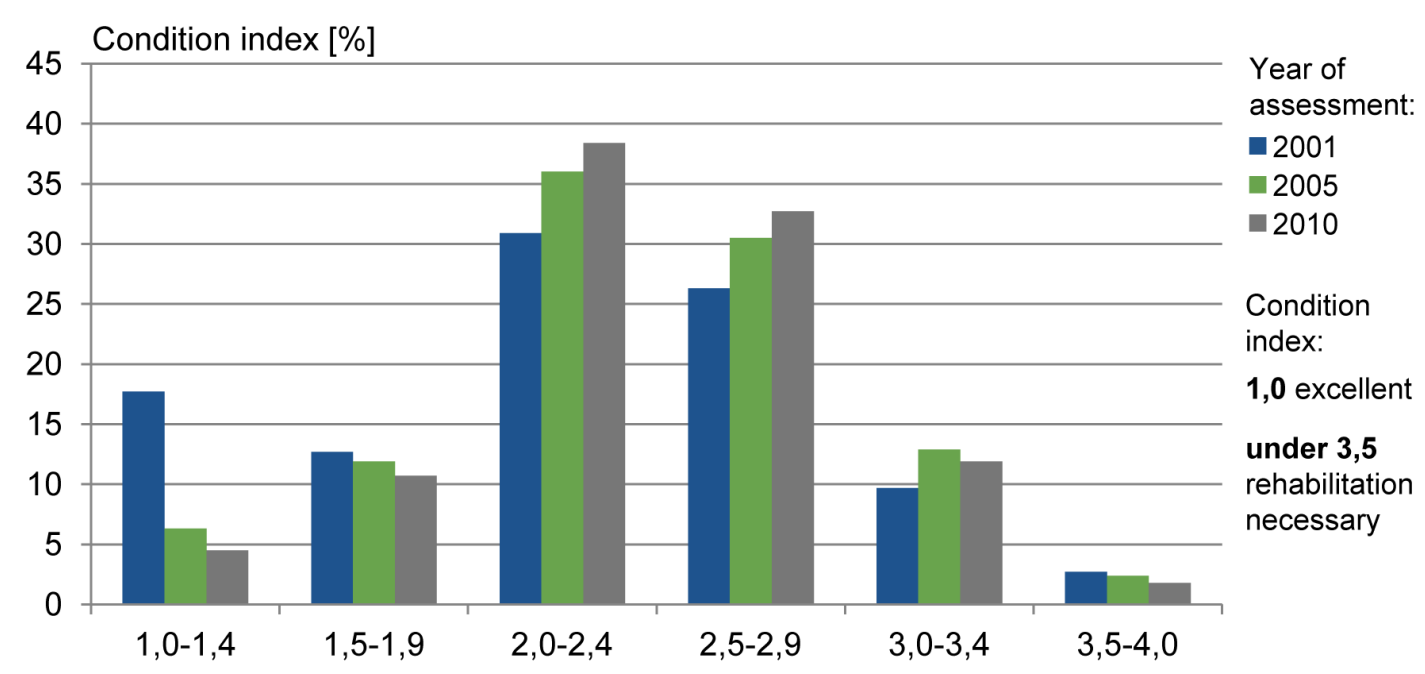

Figure 3. Percent of federal road bridges classified in the six condition classes, 3,5-4,0 means insufficient and the particular bridge has to be closed [8]

Within the last ten years the condition index of the bridge portfolio has shifted to an overall inferior state. Especially the bridge condition indices from 2,5 to 3,4 often imply that cracks have been found during steel bridge inspections. The reasons can be manifold but for a rehabilitation high frequency mechanical impact treatment can be a valuable method to increase the fatigue resistance of bridges damaged.

Furthermore, many cracks are also caused by increasing loads. As to be seen in Figure 4, since the 1950s the permitted axle loads have increased slightly 


\title{
ROMANIAN JOURNAL \\ OF TRANSPORT INFRASTRUCTURE
}

\author{
Thomas Ummenhofer, Philipp Weidner, Tim Zinke \\ New and existing bridge constructions- increase of fatigue strength of welded joints by high frequency \\ mechanical impact treatment
}

and the traffic on highways has significantly grown. Considering that most highway bridges have been built during the 1970s, there is still an enlargement of the traffic of about $250 \%$. These developments often require an improvement of details exposed to fatigue stress. Because of the numerous applications named the investigation on HFMI-methods will be presented in depth in the following.

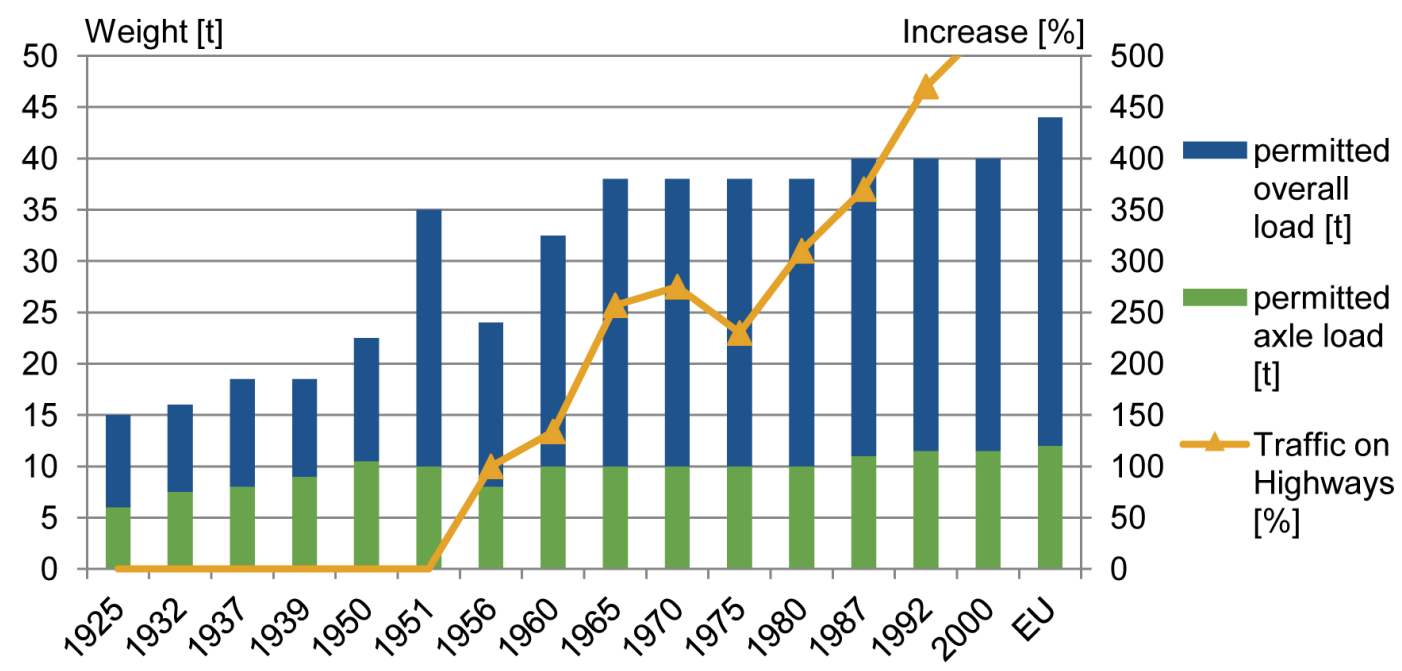

Figure 4. Development over time of the loads and the traffic on German highway bridges, traffic increase related to year 1951/1952 [1]

\section{HFMI-TREATMENT FOR IMPROVING FATIGUE STRENGTH}

\subsection{Mode of operation}

For conventional hammer peening as well as for HFMI, the working principal is the same. Cylindrical indenters are accelerated against a welded component or structure with a certain frequency [18]. The result is a strain hardening of the surface layers due to the plastic deformation of the weld toe as well as the insertion of compressive residual stresses $[9,13]$. The compressive residual stresses superimpose with the notch stresses resulting from the load applied and thus decrease the tensile stress level at the weld toe.

\subsection{HFMI-methods}

On the basis of comprehensive research work, different HFMI-methods have been approved for post weld treatment of welded joints. These include HiFIT $[11,15]$, UIT $[3,10,11]$ and some more. Compared to conventional 
hammer peening methods with a frequency in the range of $25-100 \mathrm{~Hz}$ [4], these methods operate at higher frequencies $\geq 150 \mathrm{~Hz}$ and as a result a higher overlap rate of the single indents is observed. This ensures a more uniform plastic deformation of the weld toe and provides a better finish of the surface. For quality assurance reasons different approaches exist. Considering HiFITtreatment, besides a visual inspection, a scale device for controlling a sufficient depth of indentation has been developed in order to meet quality assurance aspects. More guidance on this issue is given in $[4,6,11]$.

\subsection{Design recommendations}

Figure 2 presents two design proposals to account for a benefit after the application of post weld treatment methods. Using these proposals, an additional increase of FAT classes can be claimed depending on the material yield strength. For conventional hammer peening a design proposal developed by Haagensen and Maddox [4] is shown by the dashed line. This proposal differentiates only between mild steels and high strength steels and assumes a slope of $m=3$. Since an increasing benefit has been observed with higher material yield strength for HFMI-treated welds, a first proposal has been developed by Weich [14], adjusting the slope of the S-N curves to $\mathrm{m}=5$ on the basis of extensive fatigue testing data. This proposal has been revised and further developed by Yildirim and Marquis [18]. Using collected data from 45 data sets for axially loaded test specimens, tested at $\mathrm{R}=0.1$ stress ratio, an empirical relationship between material yield strength and fatigue strength of HFMI-treated welds was established. As a result of the investigated joints, including longitudinal attachments, transverse- and butt welds, an increase of $12.5 \%$ in fatigue strength for every $200 \mathrm{MPa}$ increase in material strength $\mathrm{f}_{\mathrm{y}}$ was found to be an appropriate formulation [18]. This proposal has also been adopted in [7] and is shown by the solid line in Figure 5. 
ROMANIAN JOURNAL

OF TRANSPORT INFRASTRUCTURE

Thomas Ummenhofer, Philipp Weidner, Tim Zinke

New and existing bridge constructions- increase of fatigue strength of welded joints by high frequency mechanical impact treatment

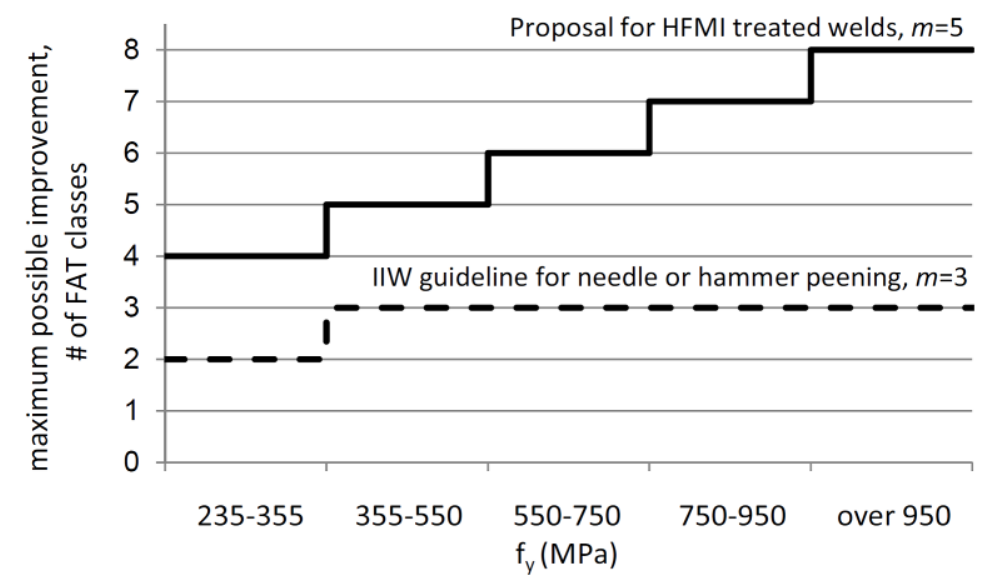

Figure 5. Proposed maximum increase in FAT classes depending on material yield strength $\mathrm{f}_{\mathrm{y}}[7,18]$

\section{WELDED JOINTS SUSCEPTABLE TO FATIGUE \& EVALUATED DATA}

In this paper butt welded joints which are frequently used in welded structures are considered. Figure 6 shows the FAT classification of butt welded joints according to IIW-Recommendations [5] and DIN EN 1993-1-9 (EC3) [2].

\begin{tabular}{|l|l|l|l|l|l|l|}
\hline 212 & $\begin{array}{l}\text { Transverse butt weld made in shop in } \\
\text { flat position, NDT } \\
\text { weld reinforcement }<0.1 \cdot \text { thickness }\end{array}$ & & $\begin{array}{l}\text { Weld run-on and run-off pieces to be used and subse- } \\
\text { quently removed. Plate edges ground flush in direction } \\
\text { of stress. Welded from both sides. Misalignment }<5 \% \\
\text { of plate thickness. }\end{array}$ \\
\hline \hline
\end{tabular}

Figure 6. FAT-classification according to IIW-Recommendations [5] (top) and according to EC3 [2] (bottom)

According to EC3 and IIW-Recommendations FAT 90 can be assigned for butt welded joints welded from both sides. Applying the latest design proposal according to [18] and [7] (see Figure 5) to the joint design in Figure 6 
the following FAT classes in the last column of Table 1 can be claimed after HFMI-treatment. In addition the benefit is given in number of FAT classes within brackets.

Table 1. FAT classes for HFMI-treated joint in Figure 3 depending on material yield strength $f_{\mathrm{y}}$ according to [18] and [7], $\mathrm{m}=5$

\begin{tabular}{|c|c|c|}
\hline \multirow{2}{*}{ Welded joint } & $\begin{array}{c}\text { Steel } \\
\text { grade }\end{array}$ & $\begin{array}{c}\text { FAT for HFMI: } \Delta \sigma_{\mathrm{c}, 95 \%} \text { at } 2 \cdot 10^{6} \text { cycles for } \\
\text { design, } \mathrm{t} \leq 25 \mathrm{~mm}, \mathrm{~m}=5 \text { for FAT classes } \\
\text { according to IIW [5] and EC3 [2] }\end{array}$ \\
\hline & S355J2 & 140 (4 FAT classes) \\
\cline { 2 - 3 } & S690QL & 180 (6 FAT classes) \\
\hline
\end{tabular}

Originally the design proposal in Figure 5 refers to the FAT classification of IIW-Recommendations [5] and is intended to be used for new structures treated with HFMI. Within the Research project REFRESH [11] a data basis concerning the applicability of HFMI-methods for new and existing structures has been developed. Thus, the application of HFMI-methods for new structures as well as a verification of the design FAT classes in Table 1 are presented in section 5.1. An application for existing structures is investigated in section 5.2.

\section{RESULTS}

\subsection{Application for new structures}

To evaluate the effectiveness of HFMI-treatment for new structures, fatigue tests on butt welded joints of the steel grades S355J2 and S690QL with a plate thickness of $16 \mathrm{~mm}$ were conducted. In Figure 7 the S-N curves for as welded (black broken curve) and HFMI-treated specimens (green dashed curve) are given for the joints made of S355J2. The red curve with a FAT value of 140 and a slope of $m=5$ represents the HFMI design curve and is conservative with the fatigue test results achieving FAT 176. Beyond that, the change in slope following the design proposal according to $[7,18]$ in Table 1 is reasonable and matches the data evaluated. In case of the butt welded joints made of S690QL, the same conclusions can be drawn. Compared to the S355J2-joints a lower fatigue strength is observed for the as welded specimens; on the other hand, with a FAT value of 210, a significant higher fatigue strength is observed after 


\section{ROMANIAN JOURNAL \\ OF TRANSPORT INFRASTRUCTURE}

Thomas Ummenhofer, Philipp Weidner, Tim Zinke

New and existing bridge constructions- increase of fatigue strength of welded joints by high frequency mechanical impact treatment

HFMI-treatment indicating an increasing efficiency for steels with a higher material yield strength (see Figure 8). However, a FAT 180 HFMI-design curve is still conservative with the data and can be used for new structures following HFMI-treatment.

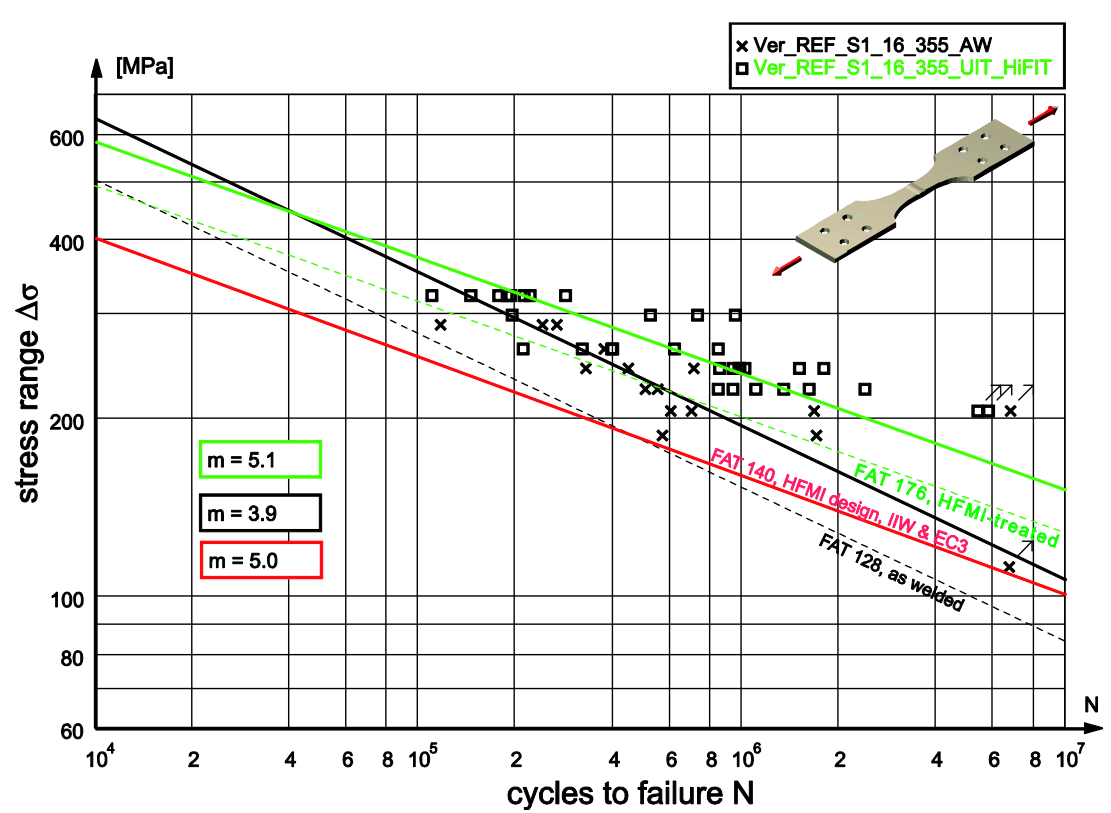

Figure 7. S-N curves for butt welded joints with / without HFMI-treatment and design $\mathrm{S}-\mathrm{N}$ curve according to Table $1, \mathrm{R}=0.1, \mathrm{~S} 355 \mathrm{~J} 2$

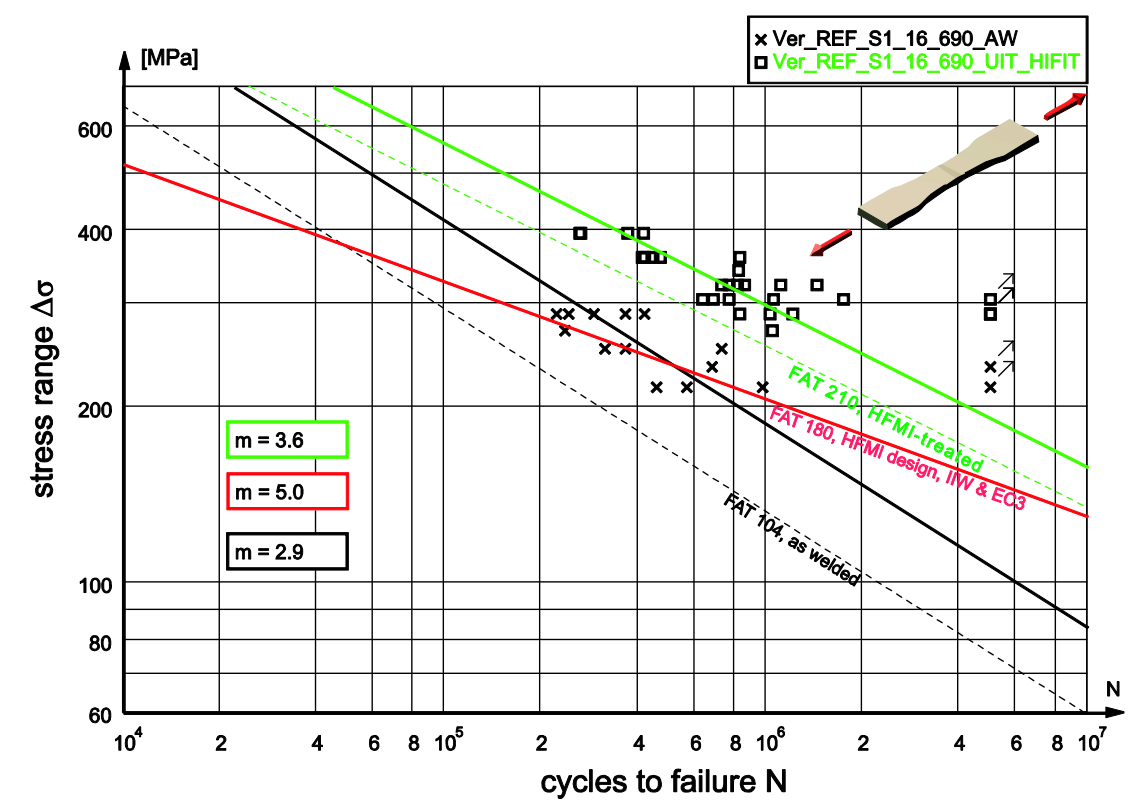

Figure 8. S-N curves for butt welded joints with / without HFMI-treatment and design $\mathrm{S}-\mathrm{N}$ curve according to Table $1, \mathrm{R}=0.1, \mathrm{~S} 690 \mathrm{QL}$ 


\subsection{Application for existing structures}

In order to investigate the effectiveness of HFMI-treatment for existing structures and to verify the applicability of the design proposal in Table 1 for these structures, fatigue tests have been conducted using joints with a fatigue preload [11]. To facilitate a comparison, the dimensions of the specimens have been retained. Figure 9 shows the influence of HFMI-treatment subsequent to the application of a fatigue preloading for the joints made of S355J2. It must be emphasized that only the cycles after HFMI-treatment are used for evaluation. For determining the load levels of the fatigue preloading the results of the as welded joints in Figure 6 were utilized, using an evaluation with a fixed slope of $\mathrm{m}=3$ according to EC3 [2]. Thus, a S-N curve with a FAT value of 103 which has been used for preloading is even higher than the design values given in Figure 6 . This has been confirmed by fatigue failures in the preloading phase which have been excluded from the evaluation in Figure 9. Following this procedure, the specimens were fatigue tested until reaching the design life and subsequently HFMI-treated in order to continue testing until rupture. As it can be seen in Figure 9, the specimens exhibit a fatigue strength that is nearly equal to the fatigue strength of new HFMI-treated joints in Figure 7. Besides that, the design proposal according to $[7,18]$ is also suitable for preloaded specimens.

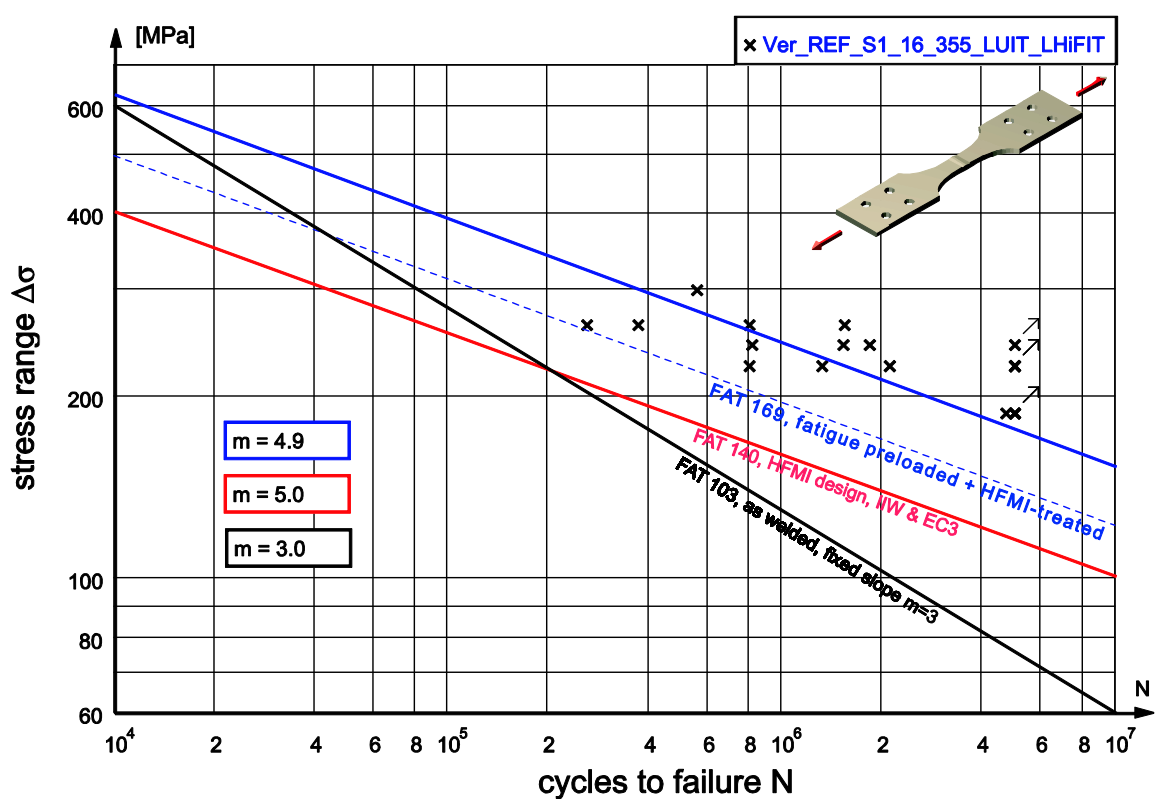

Figure 9. S-N curves for butt welded joints: influence of HFMI-treatment after fatigue preloading and design $\mathrm{S}-\mathrm{N}$ curve according to Table $1, \mathrm{R}=0.1, \mathrm{~S} 355 \mathrm{~J} 2$ 
Considering the butt welded joints made of S690QL, a FAT-value of 224 for the preloaded and HFMI-treated joints is even higher than the FAT-value of the new HFMI-treated joints in Figure 8. Also in this case the design proposal according to $[7,18]$ with a FAT value of 180 is suitable and can be described as a conservative approximation of the results. For definition of the level of load for preloading, a design FAT class of 90 or 125 was used. Since no significant difference for the different preloading-levels was observed, the results are evaluated together in Figure 10.

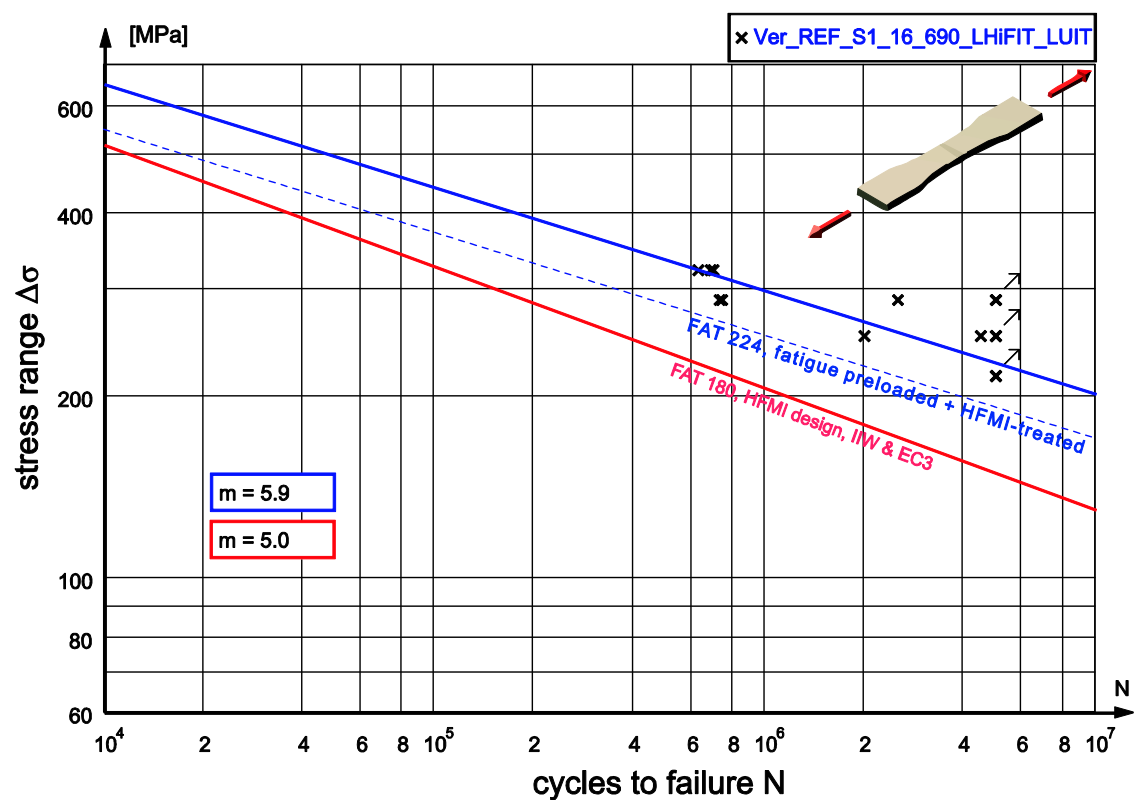

Figure 10. S-N curves for butt welded joints: influence of HFMI-treatment after fatigue preloading and design $\mathrm{S}-\mathrm{N}$ curve according to Table 1, R = 0.1, S690QL

Further examinations prove, that an initial crack depth after preloading should not exceed a crack depth of a $\geq 0.5 \mathrm{~mm}$ [11]. Following this, the same fatigue strength as for new HFMI-treated joints can be applied for HFMItreatment after preloading.

\section{IMPLEMENTATION INTO PRACTISE: EXAMPLES OF USE}

Based on the results of REFRESH [11] the HFMI-method HiFIT has been applied successfully for new bridge constructions, such as the road and tramway bridge over the "Schenkendorfstraße" in Munich but also for existing bridges, 


\title{
ROMANIAN JOURNAL \\ OF TRANSPORT INFRASTRUCTURE
}

\author{
Thomas Ummenhofer, Philipp Weidner, Tim Zinke \\ New and existing bridge constructions- increase of fatigue strength of welded joints by high frequency \\ mechanical impact treatment
}

such as the "Ruhrstrombridge" in Mühlheim and many more. Additional information for practical application can be found in [11].

\section{CONCLUSIONS}

Considering the condition of many bridge constructions, especially those made of steel, there is a strong need for methods that are suitable for enhancing the fatigue life of new and particularly for existing structures. The condition of the railway and road bridge stock in Germany has been presented and reasons for the current needs have been pointed out. Given the problems of a large number of buildings which require rehabilitation measures, HFMI-methods for improving the fatigue behavior of those structures were investigated. It has been shown that HFMI-methods are very efficient in order to increase the fatigue strength of new structures as well as to enhance the fatigue life of existing structures. Using HFMI-methods for preloaded joints, it was observed that the same effectiveness can be achieved for joints which have reached calculated service life. The analysis of currently available design proposals for HFMItreated joints show that the proposals in $[7,18]$ are suitable for new as well as for existing structures and can be used for design. Several examples of practically applied post weld treatment within bridge building projects illustrate the potential of these methods.

\section{REFERENCES}

[1]. BMVBS: "Bericht über die Qualität, Dauerhaftigkeit und Sicherheit von Spannbetonbrücken". Vorlage an den Ausschuss für Verkehr, Bau und Stadtentwicklung des Deutschen Bundestages, Berlin, 2006.

[2]. DIN EN 1993-1-9, 2010-12 "Eurocode 3: Bemessung und Konstruktion von Stahlbauten - Teil 1-9: Ermüdung”.

[3]. A. DÜRR: "Zur Ermüdungsfestigkeit von Schweißkonstruktionen aus höherfesten Baustählen bei Anwendung von UIT-Nachbehandlung". Dissertation, Universität Stuttgart, Institut für Konstruktion und Entwurf, 2007.

[4]. P.J. HAAGENSEN, MADDOX, S. J.: "IIW recommendations on post weld fatigue life improvement of steel and aluminium structures". IIW document XIII-2200r7-07, 2010. 


\title{
ROMANIAN JOURNAL OF TRANSPORT INFRASTRUCTURE
}

\author{
Thomas Ummenhofer, Philipp Weidner, Tim Zinke \\ New and existing bridge constructions- increase of fatigue strength of welded joints by high frequency \\ mechanical impact treatment
}

[5]. A. HOBBACHER: "Recommendations for Fatigue Design of Welded Joints and Components". IIW document IIW-1823-07 ex XIII-2151r4-07/XV-1254r4-07, International Institute of Welding, December 2008.

[6]. G. MARQUIS, Z. BARSOUM: “Fatigue Strength Improvement of Steel Structures by High Frequency Mechanical Impact: Proposed Procedures and Quality Assurance Guidelines". IIW document XIII-2453r1-13, International Institute of Welding, 2013.

[7]. G.B. MARQUIS, E. MIKKOLA, H.C. YILDIRIM, Z. BARSOUM: "Fatigue strength improvement of steel structures by high frequency mechanical impact: Proposed fatigue assessment guidelines". IIW Document XIII-2452r1-13, International Institute of Welding, 2013.

[8]. T. NEUMANN, P. HAARDT: “Intelligent Bridges - Adaptive Systems for Information and Holistic Evaluation in Real Time". Proceedings of the Sixth International Conference on Bridge Maintenance, Safety and Management, Stresa, Italy, 8-12 July, 2012.

[9]. T. NITSCHKE-PAGEL, DILGER, K., WEICH, I., UMMENHOFER, T.: "Residual stresses and near surface material condition of welded high strength steels after high frequency mechanical post-weld treatments". IIW-Document XIII-2153-07, International Institute of Welding, 2007.

[10]. R. PUTHLI et al.: "Detaillösungen bei Ermüdungsfragen und dem Einsatz hochfester Stähle bei Offshore Windenergieanlagen". Forschung für die Praxis P633, FORSCHUNGSVEREINIGUNG STAHLANWENDUNG E.V (FOSTA), VERLAG UND VERTRIEBSGESELLSCHAFT MBH, Düsseldorf, 2008.

[11]. T. UMMENHOFER et al.: "REFRESH - Lebensdauerverlängerung bestehender und neuer geschweißter Stahlkonstruktionen". Forschung für die Praxis P702, FORSCHUNGSVEREINIGUNG STAHLANWENDUNG E.V (FOSTA), VERLAG UND VERTRIEBSGESELLSCHAFT MBH, Düsseldorf, 2011.

[12]. T. UMMENHOFER, S. HERION, R. PUTHLI, P. WEIDNER: "Effects of post weld treatment and loading condition on the fatigue life of ultra high strength steels". Proceedings of the the Twenty-First International Offshore and Polar Engineering Conference (ISOPE-2011), Maui, Hawaii, USA, June 19 - 24, 2011.

[13]. T. UMMENHOFER, WEICH, I., NITSCHKE-PAGEL, T.: "Lebens- und Restlebensdauerverlängerung geschweißter Windenergieanlagentürme und anderer Stahlkonstruktionen durch Schweißnahtnachbehandlung”. Stahlbau 74 (2005), $412-$ 422. 


\section{ROMANIAN JOURNAL \\ OF TRANSPORT INFRASTRUCTURE}

Thomas Ummenhofer, Philipp Weidner, Tim Zinke

New and existing bridge constructions- increase of fatigue strength of welded joints by high frequency mechanical impact treatment

[14]. I. WEICH: "Ermüdungsverhalten mechanisch nachbehandelter Schweißverbindungen in Abhängigkeit des Randschichtzustands". Dissertation, Technische Universität Braunschweig, 2009.

[15]. I. WEICH: “Granjon Prize Category C: Edge layer condition and fatigue strength of welds improved by mechanical post weld treatment". IIW Document XIII-2265-09, International Institute of Welding, 2009.

[16]. I. WEICH, UMMENHOFER, T., NITSCHKE-PAGEL, TH., DILGER, K., ESLAMI, H.: "Fatigue behaviour of welded high-strength steels after high frequency mechanical postweld treatments". Welding in the World (2009) / International Institute of Welding (IIW) Bd. 53 (2009), R322-R332.

[17]. P. WEIDNER, S. HERION, R. PUTHLI, T. UMMENHOFER: "Lebensdauerverlängerung von geschweißten Verbindungen aus Rundhohlprofilen (Extension of the fatigue life of welded joints made of circular hollow sections)". Stahlbau 80 (2011), 502-512.

[18]. H.C. YILDIRIM, G.B. MARQUIS: "Fatigue strength improvement factors for high strength steel welded joints treated by high frequency mechanical impact". International Journal of Fatigue 44 (2012), 168-176. 